\title{
Ground Electromagnetic and Electric Studies for Um Salim Gold Mine, Central Eastern Desert, Egypt
}

\author{
Mohamed A. El-Sadek, Ibrahim M. M. Al-Alfy*, Hussein F. Abd El Salam, Mostafa A. M. Zaeimah \\ Nuclear Materials Authority, Cairo, Egypt \\ Email: *ibelalfy@yahoo.com
}

How to cite this paper: El-Sadek, M. A., Al-Alfy, I. M. M., El Salam, H. F. A., \& Zaeimah, M. A. M. (2021). Ground Electromagnetic and Electric Studies for Um Salim Gold Mine, Central Eastern Desert, Egypt. Journal of Geoscience and Environment Protection, 9, 129-139.

https://doi.org/10.4236/gep.2021.98008

Received: June 7, 2021

Accepted: August 14, 2021

Published: August 17, 2021

Copyright $\odot 2021$ by author(s) and Scientific Research Publishing Inc. This work is licensed under the Creative Commons Attribution International License (CC BY 4.0).

http://creativecommons.org/licenses/by/4.0/

\begin{abstract}
Horizontal Loop Electromagnetic (HLEM) and Induced Polarization (IP) methods have been carried out within Um Salim gold mine area. The study area reveals special importance, as it comprises rock units, which show some indication of the presence of various mineralization. The result of HLEM has shown significant and well-defined conductive zones are recorded along with the four used frequencies $(110 \mathrm{~Hz}, 440 \mathrm{~Hz}, 1760 \mathrm{~Hz}$, and $7040 \mathrm{~Hz})$ at the station $2,782,900$ and station 2,782,880 of two (HLEM) profiles $(596,050 \mathrm{~N} \&$ $596,240 \mathrm{~N}$ ) respectively, that may reflect the sources of the conductive bodies are situated at shallow depths continued to considerable depths. The result of IP exhibits a strong anomalous zone centered at stations 140 and 240, with chargeability values ranging ( 37 to more than $120 \mathrm{mV} / \mathrm{V}$ ) on chargeability model section, and corresponding to high resistivity on resistivity model section which may reflect considerable surface and subsurface disseminated mineralization. Through the integration between HLEM and IP a core drilling is recommended at station 140 on IP profile which coincides with station $2,782,850$ on HLEM profile $(596,240 \mathrm{~N})$ to a depth of concerning $100 \mathrm{~m}$ take a look at the thickness, depth, and grade of mineralization.
\end{abstract}

\section{Keywords}

Electromagnetic, Induced Polarization, Gold Mineralization

\section{Introduction}

Um Salim area is situated in the central eastern desert of Egypt (Figure 1). It is situated between longitudes $33^{\circ} 53^{\prime} \mathrm{E}$ and $34^{\circ} 00^{\prime} \mathrm{E}$ and latitudes $25^{\circ} 08^{\prime} \mathrm{N}$ and $25^{\circ} 11^{\prime} \mathrm{N}$, and approximates eighty-four $\mathrm{km}^{2}$ in surface area. The area under in- 
vestigation reveals a special importance, as it comprises rock units, which show some indication of the presence of various mineralization (iron hydroxides, carbonates, sulphides, micas, and native gold) as detected by the previous geological, geochemical, and geophysical studies (Klemm et al., 2001).

(El-Sadek, 2009) studied Um Salim gold mine using airborne spectrometric and magnetic data. He conducted that, Um Salim gold mine is related to terribly with very low aero-radio spectrometric levels and the location of the gold deposit is related to cross fault dominance ( $\mathrm{NE}$ and $\mathrm{NW}$ ). Also, through general radiometric signatures for the gold mine, he illustrated that there are two radio spectrometric anomalies; these two anomalies may point to an alteration rim around the gold main mineralization or may be another location for Au deposits.

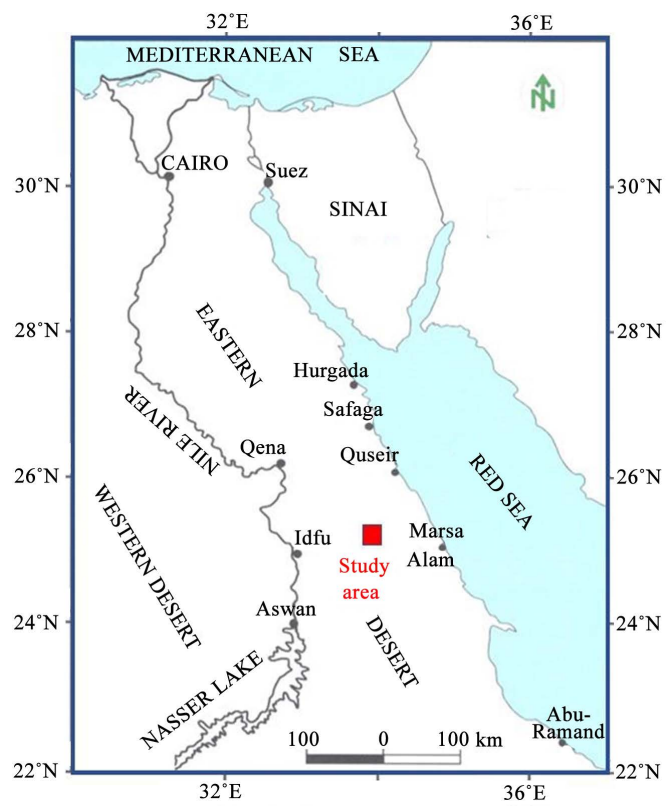

(a)

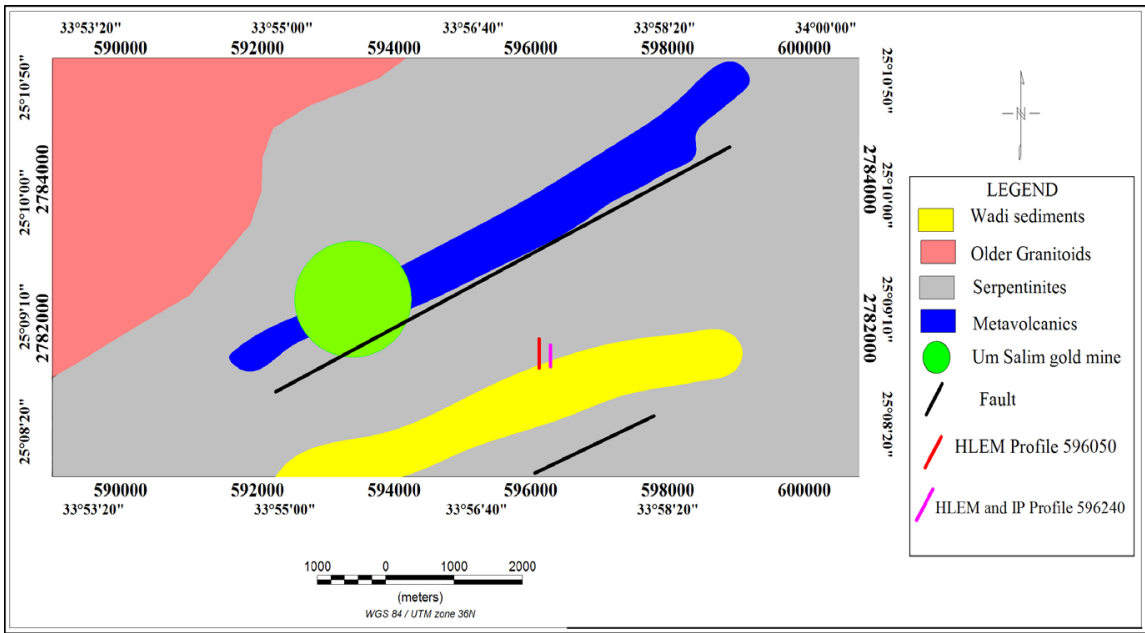

(b)

Figure 1. (a) Location map of the study area; (b) Geological map of Um Salim area, Central Eastern Desert, Egypt. 
So, Horizontal Loop Electromagnetic (HLEM) and Induced Polarization (IP) methods were selected to study southwest anomaly in order to: 1) Follow the exposed surface mineralization at deeper depths and obtain information about the probable lateral and vertical extensions; 2) Integrated interpretation of the various geophysical results in collaboration with the available pre-existing information guided the exploratory drilling operations in the studied area.

\section{Geologic Setting}

The gold veins are intruded through many types of rock. They include ophiolites (serpentinite-metagabbro-sheeted dyke complexes-pillow lava sequence) in a schistose pelitic matrix, together with an island-arc association made up of metamorphosed calc-alkaline volcanics and volcaniclastic sediments of comparable com-position. Alteration of the ophiolitic complex to talc-carbonate is common and broad belts have been mylonitized into schistose rocks, formerly explained as mudstones (Marten, 1986). The rock units in the study area can be classified into the following main groups, starting with the oldest.

\section{Shadli Metavolcanics}

They are normally interbedded with the First Basement (or Geosynclinal) Sediments and commonly found as flows, sills and thick sheet-like bodies, of (El-Shazly, 1977). The group originally includes a complex formation of surface and submarine volcanic effusions of basic up to acidic composition.

\section{Serpentinites and Related Rocks}

The serpentinites and related rocks are considered a part of the Pan-African ophiolites (Elgaby et al., 1988). The massive serpentinites consist of antigorite, talc, chlorite, tremolite and carbonate mineral assemblages.

\section{Older Granitoids}

Older granitoids include the assemblage of felsic plutonic rocks of essentially intermediate composition. (El Ramly \& Akaad, 1960) mentioned that these rocks are thought to have originated by granitization of older rocks, including both metasediments, usually of an amphibolitic nature, and epidioritic metagabbroid rocks. They are definitely younger than the geosynclinal sediments and associated metavolcanics.

\section{Quaternary and Wadi Sediments}

They consist of sand, pebbles and rare boulders. They constitute the surficial cover of the main Wadis and tributaries. They are generally formed by the weathering of local and adjacent rocks and their accumulation have been occurred during quaternary time.

Mineralogically, the veins fundamentally consist of quartz, jointly with small quantities of micas, sulphides, iron hydroxides, carbonates, and native gold. Generally, the most dominant sulphides minerals in the veins are pyrite, followed by arsenopyrite. Other subordinate sulphides inclusive chalcopyrite, pyrrthotite, sphalerite, and galena are ordinarily identified, whereas marcasite and niccolite are very scarcely detected (Sharara \& Vennemann, 1999). Analyzes of various 
rocks in the ANS-Nubian-Arabian Shield (for example, serpentine sedimentary rocks, basalts, limestones) indicate exposed gold concentrations of $20-50 \mathrm{ppm}$ in the ventral and sub-abdominal sediments, and concentrations close to 200 ppb in serpentine (Klemm et al., 2001).

Four deformational events are distinguished in the Neoproterozic rocks. Event D1 a pure compression stress regime with $\sigma 1$ stress axis trending NNW-SSE to $\mathrm{N}-\mathrm{S}$ represents an early shortening event associated with the Pan-African thrusting, during which intra-oceanic arcs and plateaus were accreted. Event D2 is characterized by structures developed under ENE-WSW compressional regime (shortening event) and is considered as the early stage of the second episode of collision within the Pan-African orogeny. Event D3 transpressional deformation associated with E-W contraction and N-S extension. The D4 event is interpreted as a postorogenic extensional event manifested by E-W dextral strike-slip and dip-slip normal faults striking NNW-SSE to N-S and E-W, which began to occur after the emplacement of post-tectonic granites (Abdeena et al., 2007).

\section{Methodology}

\subsection{Horizontal Loop Electromagnetic (HLEM) (Slingram) Method}

It is perhaps the most popular among the mobile transmitter-receiver methods operating in the frequency domain. In this method, the source of the primary field (transmitter coil) is moved simultaneously with the receiver coil along the traverse with a fixed spacing between them. A battery-powered portable oscillator (usually multifrequency) delivers current to the transmitter coil. The receiver, identical in design, is separated from the transmitter by a fixed distance. The transmitter and receiver coils are coplanar, and in most surveys, the coils are held horizontal. A reference signal is fed to the receiver by a cable attached to the oscillator, against which the real and imaginary parts of the received signal are successively measured. The connecting cable also controls the separation between the two coils (Sharma, 1997).

Hence, the measurements were acquired at four frequencies $(110 \mathrm{~Hz}, 440 \mathrm{~Hz}$, $1760 \mathrm{~Hz}$ and $7040 \mathrm{~Hz}$ ), with a coil separation of $100 \mathrm{~m}$ and station separation of $20 \mathrm{~m}$ for two profiles. The HLEM measurements were carried out using a portable Max-Min 1 - 8 EM system. Max Min 1 - 8 system is designed for groundwater and mineral exploration, as well as for geoengineering applications. The Frequency span is extended to 8 octave-spaced frequencies from 110 to 14,080 $\mathrm{Hz}$. It has 11 coil separation cables with lengths from 12.5 to $400 \mathrm{~m}$.

\subsection{Data Reduction and Presentation}

Because the HLEM surveys were conducted in low to moderate topographic areas, a correction of the data must be applied. This correction is made automatically inside the MAX MIN EM instrument and the corrected in-phase and out-of-phase data are taking from the receiver directly. The in-phase and out-of-phase data were plotted in a two-dimensional curve, where the distance 
along the profile is represented along the $\mathrm{X}$-axis while the in-phase and out-of-phase values are represented along the $\mathrm{Y}$-axis. The resulting curve will differ in shape relying on the depth, size, width, conductivity and dip of the conductive body.

\subsection{Induced Polarization (IP) Method}

The Induced Polarization (IP) procedure is one of the foremost widely-used techniques in ore deposit quest, which might provide information concerning the lateral and vertical variations of the earth's properties. It is supported the study of secondary electric fields, generated within the ground by electric currents. It is extensively utilized due to its allergy to electronic and ionic conductors. It is being the only one that responses to low-grade disseminated mineralizations (Seigel, 1967; Bertin, 1976; Komarov, 1980; Parasnis, 1986; Sharma, 1997; Milsom, 2003). It is also used in groundwater, geotechnical and environmental exploration (Seara \& Granda, 1987; Drascovits et al., 1990; Roy et al., 1995; Oldenburg, 1996; Aristodemou \& Thomas-Betts, 2000). The two-dimension electric resistivity/IP prospecting can yield knowledge about both lateral and vertical differences of the earth's properties and may be employed in the identification of the structure and depth of buried features (Tsourlos et al, 1998).

The IP/resistivity survey was taken within the time-domain mode on one profile using the dipole-dipole array. The dipole length in this survey was $40 \mathrm{~m}$ to get reliable subsurface information to about $70 \mathrm{~m}$ depth below the ground surface. The data were composed using IRIS instrumentations; the transmitter used in the present study is VIP-5000 (IRIS, 2004) and powered by its motor generator, $220 \mathrm{~V} \mathrm{AC} 60 \mathrm{~Hz}$, 3-phase, $12.5 \mathrm{KVA}$ and the receiver used was a modern French made instrument; model Elrec-T.

\subsection{Data Reduction and Presentation}

The apparent electric resistivity and chargeability measurements were inverted into models using the RES2DINV program (Loke, 2004). This program automatically determines the two-dimensional (2-D) models for both resistivity and chargeability data that are obtained from IP/resistivity surveys (Griffiths \& Barker, 1993). This computer program employs the smoothness forced least-square inversion technique (Sasaki, 1992) to convert measured apparent IP/resistivity values to true resistivity and chargeability values and plot them on a cross-section (2D-model). On the $\mathrm{x}$-axis is the distance along with the survey profile and on the $y$-axis is the true depth. Figure 2 shows the location of two lines.

\section{Interpretation and Discussion}

\subsection{Quantitative Interpretation of HLEM Data}

\section{Profile (596,050 N-Line 1)}

This line was selected to confirm the obtained results from airborne spectrometric and magnetic data of (El-Sadek, 2009) that conducted mineralization located in southwestern anomaly and obviously appeared on gamma-ray spectrometric maps. It was carried out from south to north with a length of 500 


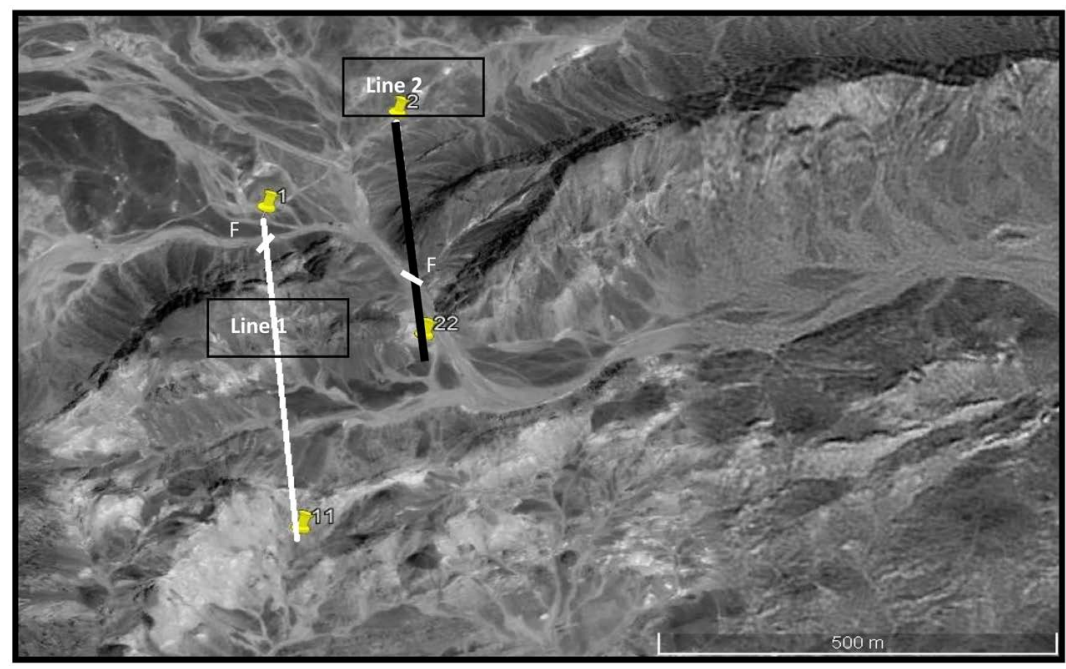

Figure 2. A Google Earth map showing the locations of the lines.

m and four frequencies $(7040 \mathrm{~Hz}, 1760 \mathrm{~Hz}, 440 \mathrm{~Hz}$ and $110 \mathrm{~Hz}$ ). The investigation of the HLEM data of this line (Figure 3) indicates a well-defined EM anomaly data at the four frequencies centered at station 2,782,900 which may reflect that the causative source is a good conductor, situated at shallow depth.

The EM anomaly has a negative peak centered at station 2,782,900 on the four frequencies $(7040 \mathrm{~Hz}, 1760 \mathrm{~Hz}, 440 \mathrm{~Hz}$ and $110 \mathrm{~Hz}$ ). The amplitude of the negative peak increases downwardly to give a well-defined two anomalies on frequency $110 \mathrm{~Hz}$ (deeper depth of penetration), which may be affected by fault (Figure 2). Meanwhile, the out-of-phase component shows high EM response at the low frequency $110 \mathrm{~Hz}$ at this zone. This may reveal the good conductor (metallic), which is buried at shallow depth. The $110 \mathrm{~Hz}$ curve is selected in calculations. The shape of the in-phase component of this anomaly reveals a thin conductive body with moderate dip $\left(60^{\circ}\right)$ to the north direction obtained from the prime curves for a rapid valuation of the dip of half-plane conductor, the depth to surface of conductor is $30 \mathrm{~m}$. The conductivity thickness is $9.1 \mathrm{mho} / \mathrm{m}$.

\section{Profile (596,240 N-Line 2)}

This line was conducted parallel to profile 596,050 with a length of $360 \mathrm{~m}$. It was measured from the north to detect the extension of southwestern anomaly, which obtained and obviously appeared from the gamma-ray spectrometric maps of (El-Sadek, 2009). Close examination of the in-phase (IP\%) and out-phase (OP\%) components of this line (Figure 4) shows the following observations:

- The in-phase components indicate that there is a broad conductive zone with maximum negative peaks centered at station 2,782,850.

- The defined EM anomaly data at the four frequencies, which may reflect that the causative source is a good conductor. The amplitudes of the in-phase components along the four frequencies are relatively high $(-40 \%)$. Meanwhile, the out-of-phase component shows low EM response at low frequency $440 \mathrm{~Hz}$ at this zone. This may reveal that a good conductor, situated at shallow depth. 


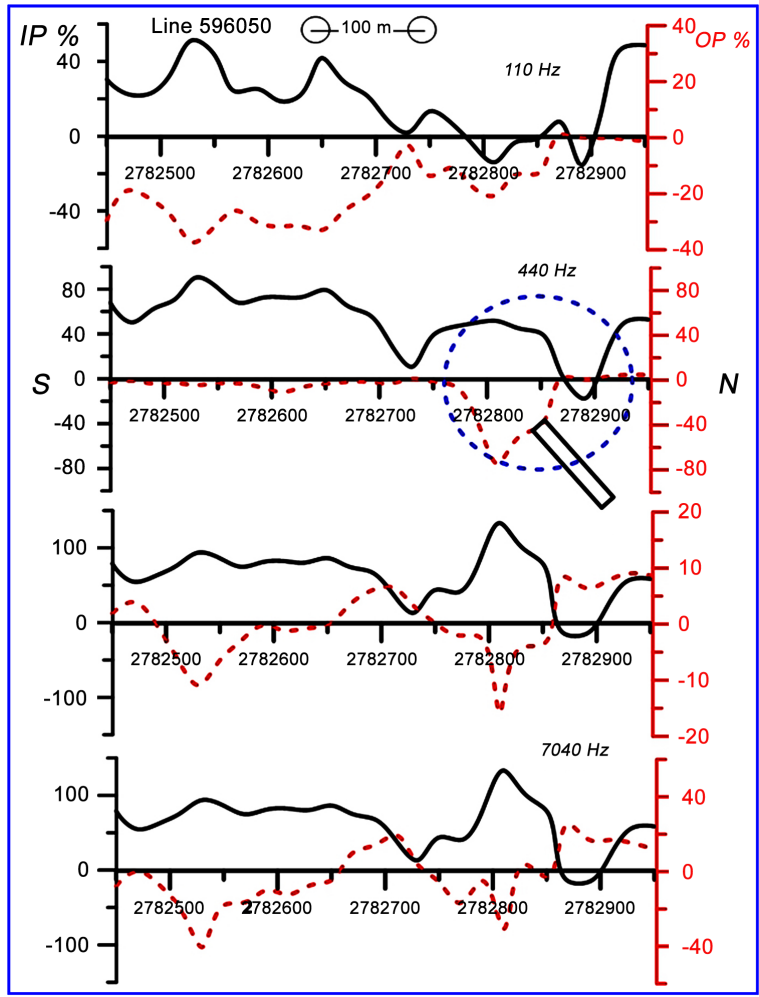

Figure 3. Horizontal loop electromagnetic profile line $(596,050)$ of Um Salim area, central eastern desert, Egypt.

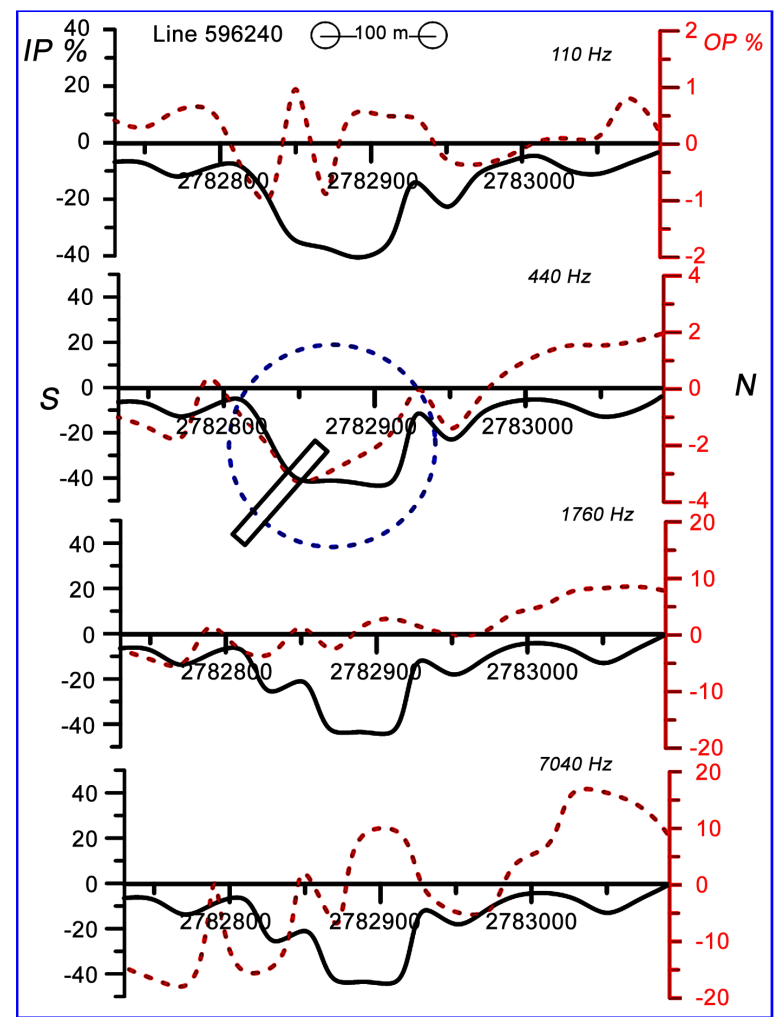

Figure 4. Horizontal loop electromagnetic profile line $(596,240)$ of Um Salim area, central eastern desert, Egypt. 
- The $440 \mathrm{~Hz}$ curve was selected in calculations. The shape of the in-phase component reveals that conductive body has a $10 \mathrm{~m}$ width with dip $\left(40^{\circ}\right)$ to the south direction. The depth to top of conductor is $25 \mathrm{~m}$ and the conductivity thickness is $18.8 \mathrm{mho} / \mathrm{m}$.

\subsection{Interpretation of Induced Polarization (IP) Data}

This profile was taken over on the same station of HLEM profile 596,240 N. It has an N-S direction with a length of $360 \mathrm{~m}$ and was carried out from the south. It was carried out with a dipole length of $40 \mathrm{~m}$ (Figure 5) to determine the top of mineralization, which has high radioelements signature (El-Sadek, 2009) to deeper depths.

Look at the resistivity model (Figure 5(a)). It is noticed that the resistivity ranges from lower than $19 \mathrm{Ohm} \cdot \mathrm{m}$ to more than $2000 \mathrm{Ohm} \cdot \mathrm{m}$, which reflects a difference in resistivity from north to south and from the surface of the earth to the depth. This reflects a horizontal and vertical change in resistivity. It is noticed that there is a major fault that divides the area into two main parts, which corresponds to field observations (Figure 2), the first from station 0 to station 210 and is distinguished by the existence of a thin crust of valley sediments with low to medium resistivity that continues to a depth of up to 20 meters and the resistivity ranges from $72 \mathrm{Ohm} \cdot \mathrm{m}$ to $500 \mathrm{Ohm} \cdot \mathrm{m}$. This is followed by the compact rocks with high resistivity, which ranges from $500 \mathrm{Ohm} \cdot \mathrm{m}$, reaches up to $1900 \mathrm{Ohm} \cdot \mathrm{m}$, and reaches a depth greater than 50 meters. On the other side of the fault, which starts from station 210 until station 340, it is characterized by a medium resistivity ranging from $72 \mathrm{Ohm} \cdot \mathrm{m}$ to $515 \mathrm{Ohm} \cdot \mathrm{m}$ and a depth greater than 60 meters and then begins the hard rock, which is characterized

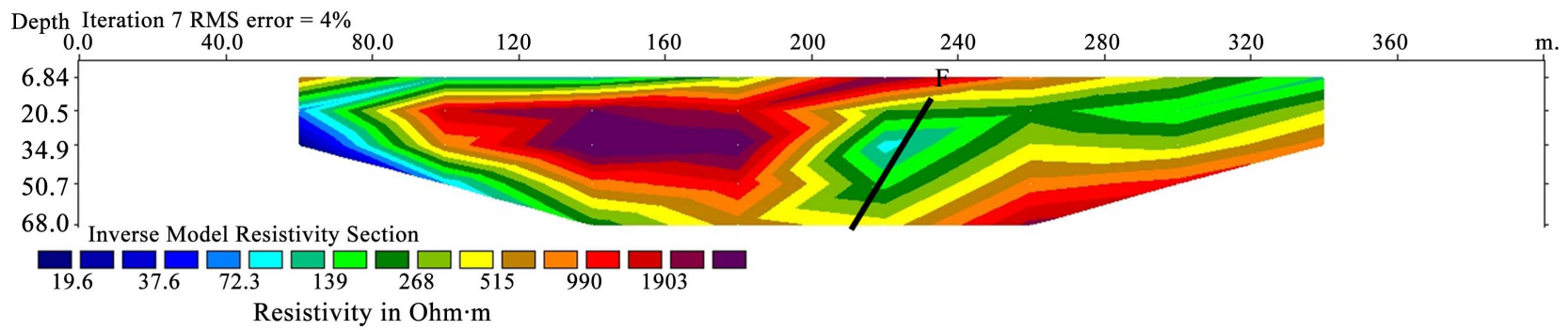

(a)

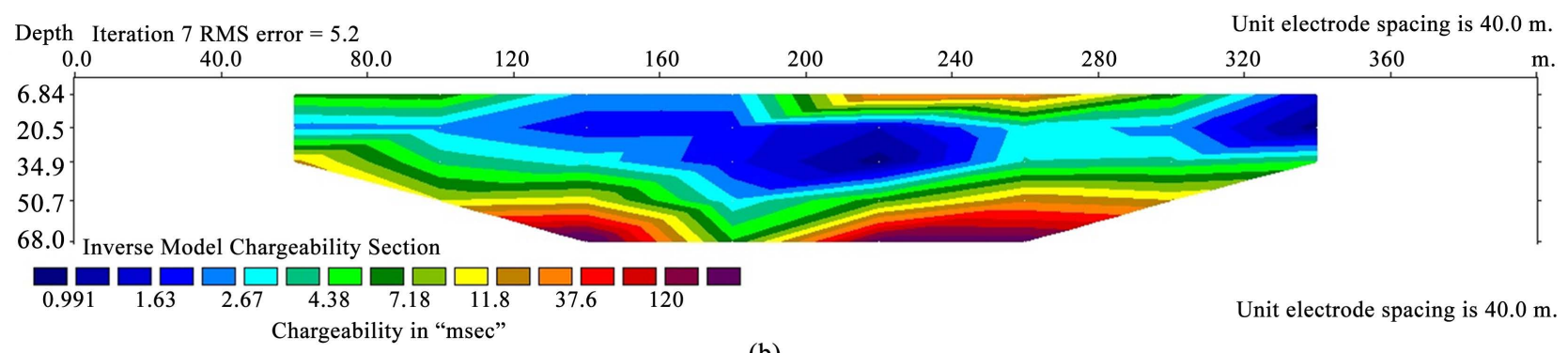

(b)

Figure 5. Dipole-dipole sections of resistivity and chargeability of dipole spacing of $40 \mathrm{~m}$ along Line 596,240 of Um Salim area, central eastern desert, Egypt. 
by a high resistivity, which reaches greater than $900 . \mathrm{Ohm} \cdot \mathrm{m}$ and extends to a depth of more than 70 meters and is open to the bottom, giving the impression that it continues to depths greater than that.

The chargeability model (Figure 5(b)) shows a relatively wide range of chargeability values ranging from 1 to more than $120 \mathrm{mV} / \mathrm{V}$. The pattern and distribution of the chargeability values reveal the presence of lateral and vertical variations of the lithological rock units, which confirms the results derived from the resistivity model. The chargeability model exhibits a strong anomalous zone centered at stations 140 and 240, with chargeability values ranging (37 to more than $120 \mathrm{mV} / \mathrm{V}$ ) $\mathrm{mV} / \mathrm{V}$. This zone of high chargeability values is corresponding to high resistive zone which may reflect considerable surface and subsurface disseminated mineralization beneath this part and varied from $35 \mathrm{~m}$ to more than $70 \mathrm{~m}$.

\section{Conclusions}

The integration between Horizontal Loop Electromagnetic (HLEM) and Induced Polarization (IP), for the area under study, can be outlined in the following conclusions:

- Significant and well-defined conductive zones are recorded along with the four used frequencies $(110 \mathrm{~Hz}, 440 \mathrm{~Hz}, 1760 \mathrm{~Hz}$, and $7040 \mathrm{~Hz})$ at the station $2,782,900$ and station 2,782,850 of two (HLEM) profiles $(596,050 \mathrm{~N} \&$ $596,240 \mathrm{~N}$ ) respectively. This may reflect the sources of the conductive bodies are situated at shallow depths continued to considerable depths.

- The chargeability model exhibits a strong anomalous zone centered at stations 140 and 240, with chargeability values ranging (37 to more than 120 $\mathrm{mV} / \mathrm{V}) \mathrm{mV} / \mathrm{V}$ and corresponding to a high resistive zone which may reflect considerable surface and subsurface disseminated mineralization.

- A core drilling, based on the geophysical results, is recommended at station 240 on IP profile which coincides with station $2,782,850$ on HLEM profile $(596,240 \mathrm{~N})$ to the depth of about $100 \mathrm{~m}$ test the depth, thickness, and grade of mineralization.

\section{Conflicts of Interest}

The authors declare no conflicts of interest regarding the publication of this paper.

\section{References}

Abdeena, M. M., \& Abdelghaffarb, A. A. (2007). Syn- and Post-Accretionary Structures in the Neoproterozoic Central Allaqi-Heiani Suture Zone, Southeastern Egypt. Precambrian Research, 185, 95-108. https://doi.org/10.1016/j.precamres.2010.12.006

Aristodemou, E., \& Thomas-Betts, A. (2000). DC Resistivity and Induced Polarization Investigations at a Waste Disposal Site and Its Environments. Journal of Applied Geophysics, 44, 275-302. https://doi.org/10.1016/S0926-9851(99)00022-1

Bertin, J. (1976). Experimental and Theoretical Aspects of Induced Polarization: Presen- 
tation and Application of the IP Method Case Histories, Geoexploration Monograph (Vol. 1, 214 p). Gebruder Bomtraeger.

Drascovits, P., Hobot, J., Vero, L., \& Smith, B. D. (1990). Induced Polarization Surveys Applied to Evaluation of Groundwater Resources, Pannonian Basin, Hungary. In Induced Polarization-Applications and Case Histories (pp. 379-396). Society of Economic Geologists (SEG).

El Ramly, M. F., \& Akaad, M. K. (1960). The Basement Complex in the South-Central Eastern Desert of Egypt between Latitudes $25^{\circ} 00^{\prime} \mathrm{N}$ and $25^{\circ} 30^{\prime} \mathrm{N}$, Geological Survey of Egypt (Paper 8, 35 p). Costa Tsoumas, Printers.

Elgaby, S., List, F. K., \& Tehrani, R. (1988). Geology, Evaluation and Metallogensis of the Pan-African Belt in Egypt. In S. Elgaby, \& R. O. Greiling (Eds.), The Pan-African Belt of Northeast Africa and Adjacent Areas (pp. 17-68). Friedr. Vieweg.

El-Sadek, M. A. (2009). Radiospectrometric and Magnetic Signatures of a Gold Mine in Egypt. Journal of Applied Geophysics, 67, 34-43. https://doi.org/10.1016/j.jappgeo.2008.08.012

Elshazly, E. M. (1977). Thegeology of the Egyptian Region. In A. E. M. Nairn, W. H. Kanes, \& F. G. Stehli, (Eds.), The Ocean Basins and Margins (pp. 379-444). Plenum Publishing Corporation.

Griffiths, D. H., \& Barker, R. D. (1993). Two-Dimensional Resistivity Imaging and Modeling in Areas of Complex Geology. Journal of Applied Geophysics, 29, 211-226. https://doi.org/10.1016/0926-9851(93)90005-J

IRIS (2004). VIP-5000 IRIS Transmitter. Time and Frequency Domain Induced Polarizationtransmitter (5 kW). In User's Manual (38 p). Orleans.

Klemm, D., Klemm, R., \& Murr, A. (2001). Gold of the Pharaohs-6000 Years of Gold Mining in Egypt and Nubia. African Earth Sciences, 33, 643-659.

https://doi.org/10.1016/S0899-5362(01)00094-X

Komarov, V. A. (1980). Electric Prospecting by the Induced Polarization Method (2nd ed., 392 p). Revised and Supplemented, Nedra.

Loke, M. H. (2004). Tutorial 2-D and 3-D Electrical Imaging Surveys (Revised Edition, 128 p). http://www.geometrics.com

Marten, B. E. (1986). Reconnaissance of Gold Deposits, Eastern Desert, Egypt. Parts I and $I I$ (pp. 1-44). Minerals International Ltd., Exploration Department, New Bury.

Milsom, J. (2003). Field Geophysics (3rd ed., 232 p). University College London.

Oldenburg, D. W. (1996). DC Resistivity and IP Methods in Acid Mine Drainage Problems: Results from the Copper Cliff Mine Tailings Impoundments. Journal of Applied Geophysics, 34, 187-198. https://doi.org/10.1016/0926-9851(95)00020-8

Parasnis, D. S. (1986). Principles of Applied Geophysics (4th ed., 402 p). Chapman and Hall. https://doi.org/10.1007/978-94-009-4113-7

Roy, K. K., Bhattacharyya, J., \& Mukherjee, K. K. (1995). Resistivity and Induced Polarization Sounding for Location of Saline Water Pockets. Exploration Geophysics, 25, 207-211. https://doi.org/10.1071/EG994207

Sasaki, Y. (1992). Resolution of Resistivity Tomography Inferred from Numerical Simulation. Geophysical Prospecting, 40, 453-464. https://doi.org/10.1111/j.1365-2478.1992.tb00536.x

Seara, J. L., \& Granda, A. (1987). Interpretation of IP Time-Domain Resistivity Soundings for Delineating Sea-Water Intrusions in Some Coastal Areas of the Northeast of Spain. Geoexploration, 24, 153-167. https://doi.org/10.1016/0016-7142(87)90089-5

Seigel, H. O. (1967). The Induced Polarization Method. In L. W. Morley (Ed.), Mining 
and Groundwater Geophysics (pp. 123-137). Geological Survey of Canada.

Sharara, N., \& Vennemann, T. W. (1999). Composition and Origin of the Fluid Responsible for Gold Mineralization in Some Occurrences in the Eastern Desert, Egypt: Evidence from Fluid Inclusions and Stable Isotopes. The First International Conference on the Geology of Africa, 1, 421-445.

Sharma, P. V. (1997). Environmental and Engineering Geophysics (475 p). Cambridge University Press. https://doi.org/10.1017/CBO9781139171168

Tsourlos, P. I., Szymanskiand, J. E., \& Tsokas, G. N. (1998). A Smoothness Constrained Algorithm for the Fast 2-D Inversion of DC Resistivity and Induced Polarization Data. Journal of the Balkan Geophysical Society, 1, 3-13. 